\title{
Soil organic carbon stock and retention rate among land uses along Didessa toposequence in humid Western Ethiopia
}

\author{
Abdenna Deressa ${ }^{1 *}$, Markku Yli-Halla² and Muktar Mohamed ${ }^{3}$
}

\begin{abstract}
Background: There is scarcity of scientific information on stocks and retention rate of soil organic carbon (SOC) among mixed farming systems in humid Western Ethiopia. The objectives of study were to determine the SOC stocks and retention rates along a 53-km long toposequence of Didessa watershed. The study was conducted in mixed farming systems (annual arable cropping, grazing, fallow, grassland, coffee agroforestry, eucalyptus agroforestry and mechanized irrigated sugarcane production) within an elevation range of 1273 to $2543 \mathrm{~m}$ above sea level.

Results: The results revealed that land use types greatly affected SOC stocks and retention rates in the upper $20 \mathrm{~cm}$ soil depth. The SOC stocks ranged from 9.27 to $13.5 \mathrm{Mg} \mathrm{C} \mathrm{ha}^{-1}(0-20 \mathrm{~cm})$ while the retention rates were $0.11,0.20$, $0.28,0.31$ and $1.14 \mathrm{Mg} \mathrm{C} \mathrm{ha}^{-1}$ year $^{-1}$ for coffee agroforestry, fallow, grazing, eucalyptus agroforestry and irrigated sugarcane production systems, respectively.

Conclusion: The retention rates demonstrated that the different farming systems are potential source of $C$ sinks. The study indicated that the farming systems are efficient in sequestering $\mathrm{SOC}$ and their benefits can be further adopted for their economic values, social significance, restoration of degraded land, and sequestration of carbon (C) in humid tropical Western Ethiopia.
\end{abstract}

Keywords: Agroforestry, Arable cropping, Fallowing land, Grassland, Sugarcane plantation

\section{Introduction}

Emission of $\mathrm{CO}_{2}$ since the industrial revolution of 1750 and land use change have increased the amount of atmospheric carbon (C) by 31\% (ESA 2000; Lal 2004a). The soil system is the largest reservoir of $C$ pool which is 3.3 times the size of atmospheric $\mathrm{C}$ and 4.5 times the size of biotic C pool (Lal 2005, 2006). African soils have an estimated soil organic carbon (SOC) stock of $166,397 \times 10^{6}$ tons $(0-100 \mathrm{~cm})$. This corresponds to $9 \%$ of the global SOC stocks and $68 \%$ of the terrestrial C pool of Africa (Henry et al. 2009). Ethiopia has an estimated SOC stock of $6459 \times 10^{6}$ tons $(0-100 \mathrm{~cm})$ and it is the

\footnotetext{
*Correspondence: dabdenna@yahoo.com

${ }^{1}$ College of Agriculture and Natural Resources Management, Wollega University, Nekemte, Ethiopia

Full list of author information is available at the end of the article
}

third largest SOC stocks in East Africa next to Tanzania and Zambia (Henry et al. 2009). However, conversion of natural ecosystem to agriculture in the tropics could cause loss of $75 \%$ or more of SOC (Lal 2005). Increased global $\mathrm{C}$ storage through sequestration into aboveground terrestrial biome and belowground stocks are feasible methods for reducing $\mathrm{CO}_{2}$ concentration in the atmosphere (ESA 2000; Lal 2004a, 2005). Global agricultural and degraded soils have high $C$ sink capacity which could be in the order of 50 to $66 \%$ of 42 to 78 gigatons (Gt) of the historic C lost to atmosphere (Lal 2005). Soils of African continent have an estimated 30\% of total global $\mathrm{C}$ sequestration potentials (Henry et al. 2009). The SOC sequestration has the potential to increase agricultural production and reduce $\mathrm{CO}_{2}$ concentration in the atmosphere (ESA 2000; Lal 2004b). 
Topography and climate vary along landscape positions and affect SOC sequestration capacity of terrestrial ecosystems. Several studies in Ethiopia have been carried out to quantify effect of vegetation, land uses and climate on SOC concentrations (Wakene 2001; Dawit et al. 2002; Lemeniha and Itanna 2004; Abraha et al. 2012; Kilic et al. 2012; Achalu et al. 2013; Nega and Heluf 2013; Getahun and Bobe, 2015). They compared the effect of conversion of native vegetation to agricultural land uses and reported higher SOC concentration from forests and grasslands compared to arable cropping and grazing land uses. However, they could not make any account of the effect of different land uses under mixed farming systems along topographic elevation over broader landscape positions on SOC stocks and retention rates.

Population pressure has pushed agriculture in Ethiopia to expand into forest on hillsides and slopping lands (Sima et al. 2011). Native vegetation is being changed into arable cropping lands with slight or no conservation measures and there has been a decreasing trend of forest coverage and SOC stocks. From 1990 to 2010 alone, 1.16Gt of $\mathrm{C}$ stocks from forest biome and 1.83Gt of SOC stocks were lost at country level (FAO 2010). Over grazing, fuel woods and production of charcoal, poor governance and land tenure system are some of the underlying causes for depletion of aboveground and belowground $\mathrm{C}$ stocks in Ethiopia (Sima et al. 2011). The inherent fragile soil properties coupled with low input agriculture have caused decline in the soil fertility within short term after conversion of marginal lands to agricultural land. Smallholder farmers fallow their field plots for three to four years until the soil fertility has partially restored. During the fallowing, controlled grazing is usually practiced. Land use changes from native vegetation to agricultural lands and the vice versa have been the sources and the sinks for atmospheric $\mathrm{CO}_{2}$. Land misuses and mismanagements have been the sources for the atmospheric $\mathrm{CO}_{2}$ while adoptions of restorative land uses and recommended management practices reduce rate of $\mathrm{CO}_{2}$ emission to atmosphere that could improve food security, water quality and environmental quality (Lal 2004a). Alley cropping system (Oelbermann et al. 2007), coffee gardening and agroforestry system (Xavier and Mendo 2011; Hombegowda et al. 2015), farm forestry and agroforestry systems (Prasad et al. 2012; Murthy et al. 2013), conversion of pasture and grazing lands to sugarcane plantation and silvo-pasture (Junior et al. 2012; Ensinas et al. 2015), soybean and maize inter-cropping (Junior et al. 2012) and preservation of vegetal biomass of sugarcane have sequestered $\mathrm{C}$ and increased the SOC stocks in many parts of the globe.

Traditional land use systems across various ecological regions and elevation gradients are practiced in
Ethiopia since immemorial (Bishaw et al. 2013). Traditional smallholder and oxen drawn arable cropping, eucalyptus and coffee agroforestry, woodlots, protected forest, fallowing, grassland systems and mechanized sugarcane plantation are some among many mixed land use systems practiced in the humid tropical Western Ethiopia. The indigenous and traditional land use systems could be restorative land use systems compared to continuous cropping with limited inputs and biomass return to the soil system. The indigenous but traditional land use systems have been practiced for centuries and could be stable systems that could reduce $\mathrm{CO}_{2}$ emission and positively impact food production, income generation, livelihoods and energy sources (Bishaw et al. 2013). Mechanized irrigated sugarcane plantation was recently introduced into Didessa watershed. However, there is scarcity of available research information on the effect of indigenous land uses and mechanized irrigated land use systems practiced along toposequence on SOC stocks and retentions on intermediate to highly weathered soils of humid tropical Western Ethiopia. Thus, the dynamics of SOC stocks and rates of retention in indigenous land use systems, and mechanized irrigated sugarcane plantation along elevation gradient forming land use catena are lacking in the horn of Africa in general and Ethiopia in particular.

Therefore, the objectives of this research were to quantify SOC stocks and retention rates of indigenous land uses systems, recently introduced modern mechanized irrigated sugarcane production system in sequestering SOC stocks and retention rates in humid tropical environment of Western Ethiopia. We hypothesized that indigenous land uses of mixed farming systems along elevation gradients were more efficient restorative systems of sequestering atmospheric $\mathrm{CO}_{2}$ compare with modern mechanized cropping system and their efficiencies vary along elevation gradients.

\section{Materials and methods Location}

Didessa watershed is located in humid tropical Western Ethiopia. The topographic map of the $52 \mathrm{~km}$ long study transect extends from $9^{\circ} 06^{\prime} 12.7180^{\prime \prime} \mathrm{N}, 36^{\circ} 28^{\prime} 22.1868^{\prime \prime}$ E to $8^{\circ} 40^{\prime} 1.9920^{\prime \prime} \mathrm{N}, 36^{\circ} 25^{\prime} 13.0308^{\prime \prime}$ E. Didessa watershed drains an area of about $9,486 \mathrm{~km}^{2}$ and agro-ecology indicated in Fig. 1. Didessa River is the tributary of Blue Nile that flows into North Western Ethiopia. The watershed covers about $5.4 \%$ of the total area of Blue Nile and contributes $6.86 \mathrm{~km}^{3}$ annual discharges which accounts to $10.7 \%$ of the total annual discharge of Blue Nile (Conway 2000). The location of study land use systems along the same toposequence is indicated in Fig. 2. 


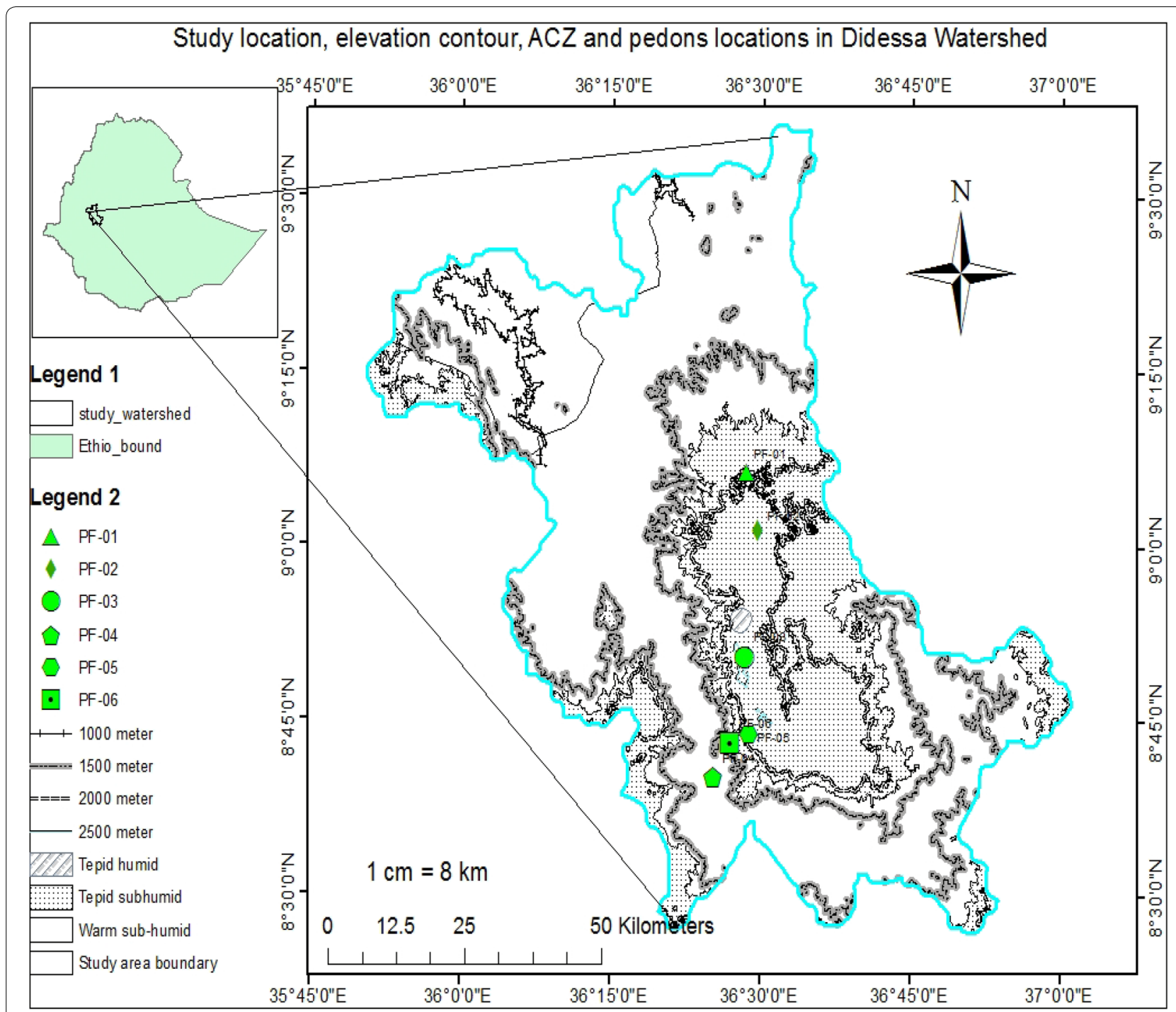

Fig. 1 Location of Didessa watershed, pedons, elevation contour intervals and Agro-ecology of the Didessa toposequence)

\section{Topography and climate}

Elevation of the watershed range from 845 to $2685 \mathrm{~m}$ and characterized by sequence of contrasted landforms. Three broad categories of topographic positions are found in study transect. These include lowland, midland and highland with elevation ranges between 845-1500, 1500-2000 and 2000-2685 m above sea level (masl), respectively. Analysis of twenty years of weather data of twelve metrological stations in and around Didessa watershed showed that the mean annual rainfall of the watershed ranged from 1400 to $1920 \mathrm{~mm}$ per annum. The rainfall in the watershed has a unimodal pattern of distribution. The watershed has three types of length of growing period (LGP) that ranges from 165 to 210 days, from 210 to 240 days, and from 240 to 300 days. The annual average temperature varies from $19^{\circ} \mathrm{C}$ in the highlands to $23^{\circ} \mathrm{C}$ in the lowland.

\section{Agro-ecologies and vegetation}

The agro-climatic zones (ACZ) of the watershed were derived from twenty years of twelve metrological stations and topographic elevation from digital elevation model. According to Hurni (1998) classification system, three agro-climatic zones were identified namely warm sub-humid lowland (180-240 LGP, $20-27.5^{\circ} \mathrm{C}$, 500-1300 masl), tepid sub-humid midland (180-240 LGP, $15-20^{\circ} \mathrm{C}, 1500-2000$ masl) and tepid humid highland (240-300 LGP, $\left.15-20{ }^{\circ} \mathrm{C}, 2000-2685 \mathrm{~m}\right)$. Grassland vegetation dominated the lowland topographic position. Mixed woodland and grassland dominated the midland 


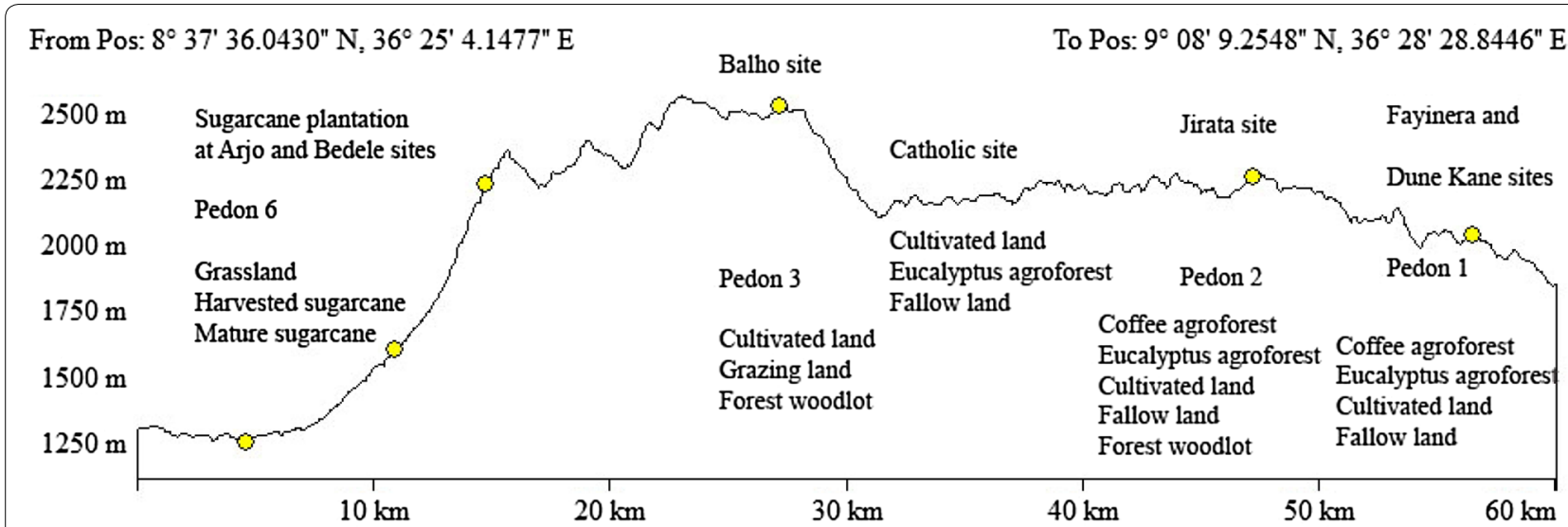

Parameters

Study sites and characteristics along toposequence

$\begin{array}{lllllll} & \text { Sugar plantation } & \text { Balho } & \text { Catholic } & \text { Jirata } & \text { Dune Kane } & \text { Fayinera } \\ \text { LGP } & 180-240 & 240-300 & 180-240 & 180-240 & 180-240 & 180-240 \\ \text { Temperature, }{ }^{\circ} \mathrm{C} & 20-27 & 15-20 & 15-20 & 15-20 & 15-20 & 15-20 \\ \text { Vegetation } & \text { Grassland } & \text { Woodland } & \text { Woodland } & \text { Woodland } & \text { Woodland } & \text { Woodland }\end{array}$

Fig. 2 Topographic map of transect of Didessa toposequence, locations of land use systems and characteristics

position while woodland dominated the highland topographic position. As one move from lowland to highland, there are shifts in vegetation types and land use systems along the study transect.

\section{Farming system of Didessa toposequence}

The farming systems are predominantly subsistent mixed crop-livestock (mostly cattle, sheep and goat) production system. In the mixed farming system, cattle provide inexpensive and easily accessible inputs required for cultivation such as draught and threshing power, while crop production supplies crop residue as feed supplement for the livestock. However, most of the grazing is carried out on communal grazing and fallow lands. Manures from calves, sheep and goats are mainly used for homestead gardens. Farm fields away from home gardens often receive manure of cattle and equines (donkeys, horses, and mules) through kraal (cattle pen during night) rotation. Tillage involves oxen plowing with simple plows that cultivate the soils to shallow depths of $15 \mathrm{~cm}$ on average (oral communication with the farmers and personal observation).

Major crops grown in the lowland (less than $2000 \mathrm{~m}$ ) of the transect include maize, sorghum, finger millet and noug while above this elevation highland potato, teff, field pea, faba bean and noug are common crops. Combination of manure and inorganic fertilizers are used for crop production but the amount of fertilizer applications is low. Farmers use di-ammonium phosphate (DAP) in combination with urea. The recommended rate of application is $100 \mathrm{~kg} \mathrm{ha}^{-1}$ year $^{-1}$ for both DAP and urea. However, some farmers use sometimes half of recommended amount and often none mainly due to economic reasons. The farming systems have traditional agroforestry system with scattered trees in the farm and grazing lands, eucalyptus woodlots at edge of farmlands, homestead coffee under shade trees. Farms of similar management history were selected by interviewing farm owners and village elders.

\section{Sampling sites and land uses selection}

Soil samples were collected at five sampling sites along the toposequence. The sampling sites were Fayinera, Dune Kane, Balho, and Lugama and Sugar plantation. At Fayinera and Dune Kane sampling sites, soil samples were collected from annual cropping land, fallow land and eucalyptus agroforestry (woodlots) that were in close juxtaposition (at edge of farmland). At Balho sampling sites, soil samples were collected from grazing and annual cropping lands. At Lugama sampling site, soil samples were collected from arable land, grazing land and home homestead coffee agroforestry. While at sugar plantation, soil samples were collected from grazing and mature sugar plantation. The soil samples collected from the distinct sampling farms (land uses) at the four sampling sites were close to each other within a distance of $10 \mathrm{~m}$ to $50 \mathrm{~m}$ from the edge of the respective land uses. Each of the sampling sites were rigorously checked for 
uniformity of soil types by augering and field characterization of physical and chemical properties, slope angle, length and aspects before sampling of soils from respective land uses and sampling sites. Flow directions of materials from farm lands at each of sampling farms and sampling sites were also considered for uniformity to aid interpretation of the results. Auger point observations to the depth of $120 \mathrm{~cm}$ were made and described according to FAO (2006) soil description field guide and checked uniformity of soil types, physically observable pedogenic features and processes. The results of field observation and description were used to verify the similarity in soil types among farms. These selection criteria, however, did not allow us to find farmlands of very similar land use characteristics, land configuration, and land management history along all the sampling sites.

\section{Soil sampling from four sampling sites}

Soil samples were collected from four representative subsistent mixed farming systems identified along the Didessa toposequence. Thirty samples were collected from each of a uniform field from cropping land, fallow land and agroforestry land at Fayinera and Dune Kane sampling sites, from cropping and grazing land at Balho sampling site, from cropping, homestead coffee agroforestry and grazing land at Lugama sampling sites, and mature sugar plantation and grassland at sugar plantation sites. All the samples were collected from $0-20 \mathrm{~cm}$ depth with an auger. The thirty samples collected from each land use were bulked to form homogenous composite samples. Generally, 360 samples were collected and then twelve composite soil samples were made out of them following standard soil sampling and bulking procedure. From each of the composite samples, representative subsamples were collected into plastic bags for analysis of soil physical and chemical properties. Foreign materials such as coarse fragments, plant roots, and leaves were removed. The samples were air dried, ground, and sieved to pass through a $2 \mathrm{~mm}$ sieve.

\section{Analysis of soil physical and chemical properties}

The air dried, sieved to pass through $2 \mathrm{~mm}$, and oven dried equivalent soil samples were analyzed for distribution of particle size determination according to modified sedimentation hydrometer procedure of Bouyoucos (Kroetsch and Wang 2006). The samples were pretreated with hydrogen peroxide to destroy organic matter and treated with sodium hexametaphosphate solution $(\mathrm{NaPO} 3)_{6}$ to disperse other soil cementing agents. The proportions of sand, silt and clay sized particle size fractions were determined. The textural classes of soils were determined from textural triangle. The $\mathrm{pH}$ of the soils was measured in supernatant suspension of soil to liquid mixture of 1:2.5 ratios. The liquids were distilled water $\left(\mathrm{pH}_{\mathrm{H} 2 \mathrm{O}}\right)$ and $1 \mathrm{M} \mathrm{KCl}(\mathrm{pH} \mathrm{KCl})$ (Reeuwijk 1992). The SOC was determined according to the Walkley-Black procedure (Reeuwijk 1992). Soil organic matter (SOM) was estimated from SOC by assuming that SOM contains $58 \%$ of SOC (Reeuwijk 1992).

The bulk density $\left(\rho \mathrm{b}, \mathrm{g} \mathrm{cm}^{-3}\right)$ of soils were calculated as the dry weight of the soil divided by volume of soil core sampler. The SOC stocks were calculated as $\mathrm{Mg} \mathrm{ha}^{-1}$ by multiplying the concentration (\%) of SOC by the respective bulk density $\left(\mathrm{g} \mathrm{cm}^{-3}\right)$ and multiplied by the depth from which samples was collected $(20 \mathrm{~cm})$. The total SOC stocks of soil profiles were determined by summing up of the SOC stocks from the respective horizons and expressed as $\mathrm{MgC} \mathrm{ha}{ }^{-1}$. The retention rates of SOC stocks were calculated as SOC stocks of the land use systems minus the SOC of the reference land use divided by the duration of the land use systems. The SOC stocks of crop land and grassland were used as reference SOC stocks with their respective indigenous land uses systems wherever available.

\section{Statistical analysis}

The map of Didessa watershed was prepared by use of ArcGIS software version 10.1 and three dimensional topographic map of study transect of Didessa toposequence was constructed using Global Mapper version 13. Soil data from similar land uses at sampling sites were treated as replications. SPSS statistics version 20 was utilized to carryout statistical analysis to determine effect of sites on SOC stocks and retention rates by. P-values of 0.05 and 0.01 were used statistically significant and highly significant differences, respectively.

\section{Results and discussion}

\section{Soil physical and chemical properties}

Table 1 indicates soil textures, soil textural classes and soil reactions of the study soils. Clay contents of upper $0-20 \mathrm{~cm}$ soil layers ranged from 16 to $34 \%$ and soil texture ranged from sandy clay to loam. Soils on more inclined surface had lower clay and higher sand contents due to surficial erosion of finer materials. The soil $\mathrm{pH}-\mathrm{H}_{2} \mathrm{O}$ in the highlands ranged from 4.48 to 5.62 and $\mathrm{pH}-\mathrm{KCl}$ ranged from 3.56 to 4.73 . The $\mathrm{pH}-\mathrm{H}_{2} \mathrm{O}$ in lowland soils ranged from 5.07 to 7.37 . The $\mathrm{pH}-\mathrm{KCl}$ ranged from 3.69 to 6.31 that is an indication of difference in exchange acidity of soils. The large variations in soil $\mathrm{pH}$ in the highland and lowland soils were due leaching of basic cations from the highland and the formation of secondary calcium carbonate in the lowland soils (Abdenna et al. 2018).

Table 2 indicates the duration of land uses in terms of years, SOC, soil bulk densities and SOC stocks of 
Table 1 Soil textures and pH in land uses of mixed farming systems of Didessa toposequence

\begin{tabular}{|c|c|c|c|c|c|c|c|c|}
\hline Districts & Sites & Land Uses & Sand, \% & Silt, \% & Clay, \% & Textural classes & $\mathrm{pH}-\mathrm{H}_{2} \mathrm{O}$ & $\mathrm{pH}-\mathrm{KCl}$ \\
\hline \multirow[t]{4}{*}{ Guto Gidda } & \multirow[t]{4}{*}{ Fayinera } & Coffee agroforestry & 61 & 23 & 16 & SC & 5.08 & 3.58 \\
\hline & & Eucalyptus agroforestry & 57 & 23 & 20 & $S L$ & 4.78 & 3.61 \\
\hline & & Cultivated land & 53 & 27 & 20 & $S L$ & 5.01 & 3.85 \\
\hline & & Short fallow & 47 & 27 & 26 & $\mathrm{SCL}$ & 4.91 & 3.71 \\
\hline \multirow[t]{5}{*}{ Guto Gidda } & \multirow[t]{5}{*}{ Dune Kane } & Coffee agroforestry & 61 & 23 & 16 & $S L$ & 5.06 & 3.72 \\
\hline & & Protected forest & 55 & 23 & 22 & $\mathrm{SCL}$ & 4.89 & 3.81 \\
\hline & & Eucalyptus agroforestry & 53 & 25 & 22 & $\mathrm{SCL}$ & 4.71 & 3.59 \\
\hline & & Cultivated land & 45 & 29 & 26 & $\mathrm{~L}$ & 4.85 & 3.69 \\
\hline & & Short fallow land & 43 & 31 & 26 & L & 5.11 & 3.83 \\
\hline \multirow[t]{4}{*}{ Diga } & \multirow[t]{4}{*}{ Jirata } & Eucalyptus agroforestry & 43 & 27 & 30 & $\mathrm{SCL}$ & 5.11 & 3.83 \\
\hline & & Cultivated land & 45 & 25 & 30 & $\mathrm{CL}$ & 5.05 & 3.73 \\
\hline & & Short fallow & 49 & 35 & 16 & $\mathrm{SCL}$ & 4.49 & 3.75 \\
\hline & & Coffee agroforestry & 43 & 25 & 32 & $\mathrm{~L}$ & 4.48 & 3.49 \\
\hline \multirow[t]{3}{*}{ Leka Dulacha } & \multirow[t]{3}{*}{ Catholic } & Cultivated land & 47 & 19 & 34 & $\mathrm{CL}$ & 5.12 & 3.93 \\
\hline & & Eucalyptus agroforestry & 37 & 37 & 26 & $\mathrm{SCL}$ & 5.01 & 3.58 \\
\hline & & Short fallow & 53 & 29 & 18 & L & 4.79 & 3.64 \\
\hline \multirow[t]{3}{*}{ Leqa Dulacha } & \multirow[t]{3}{*}{ Balho } & Grazing land & 63 & 29 & 8 & $S L$ & 4.93 & 3.67 \\
\hline & & Forest land & 41 & 33 & 26 & $S L$ & 5.16 & 3.91 \\
\hline & & Cultivated land & 57 & 21 & 22 & L & 5.62 & 4.73 \\
\hline \multirow[t]{3}{*}{ Bedele } & \multirow[t]{3}{*}{ Sugar plantation } & Sugarcane at harvest & 57 & 21 & 22 & $\mathrm{SCL}$ & 5.07 & 3.69 \\
\hline & & Grassland & 55 & 19 & 26 & $\mathrm{SCL}$ & 6.06 & 4.67 \\
\hline & & Sugarcane plantation & 49 & 21 & 30 & $\mathrm{SCL}$ & 6.17 & 4.76 \\
\hline \multirow[t]{3}{*}{ Jimma Arjo } & \multirow[t]{3}{*}{ Sugar plantation } & Grassland and forest & 41 & 25 & 34 & L & 6.13 & 4.52 \\
\hline & & Sugarcane at harvest & 49 & 17 & 34 & $\mathrm{SCL}$ & 7.37 & 6.31 \\
\hline & & Sugarcane plantation & 53 & 17 & 30 & $\mathrm{SCL}$ & 6.63 & 4.75 \\
\hline
\end{tabular}

CL clay loam, SC sandy clay, SCL sandy clay loam, SL sandy loam

the study soils. The soil bulk densities ranged from $0.83 \mathrm{~g} \mathrm{~cm}^{-3}$ in coffee agroforestry to $1.44 \mathrm{~g} \mathrm{~cm}^{-3}$ in mechanized irrigated sugarcane plantation. Within coffee agroforestry system, the soil bulk densities varied within a narrow range of 0.83 to $0.88 \mathrm{~g} \mathrm{~cm}^{-3}$. The bulk densities in smallholder eucalyptus agroforestry system ranged from 0.99 to $1.22 \mathrm{~g} \mathrm{~cm}^{-3}$, while in cultivated land use system, the bulk densities ranged from 1.08 to $1.3 \mathrm{~g} \mathrm{~cm}^{-3}$. The bulk densities in short fallow land use system also varied with very narrow range and comparable with the bulk densities in cultivated land use system. Soils from grassland and mature sugarcane plantation had comparable soil bulk densities that ranged from 1.15 to $1.32 \mathrm{~g} \mathrm{~cm}^{-3}$. The higher the soil bulk density in sugar plantation could be due to compaction of Vertisols by heavy machineries during land preparation and harvesting of canes.

\section{Soil organic carbon stocks among land uses}

Table 2 indicates the stocks of SOC among land use systems along toposequence of Didessa watershed in mixed farming systems. The stocks of SOC varied with land use systems. It ranged from $9.27 \mathrm{Mg} \mathrm{C} \mathrm{ha}^{-1}$ in grassland soils at lowland to $13.5 \mathrm{Mg} \mathrm{Cha}^{-1}$ in eucalyptus agroforestry system in the highland. The observed differences in stocks of SOC among land uses were statistically significant $(\mathrm{P}<0.05)$. In the highland topographic position, the stocks of SOC were lower in annual arable cropping compared to other land uses. At the lowland, the stocks of SOC were lower in pristine grassland compared to mechanized irrigated sugarcane production system. The lower the stocks of SOC in arable cropping is agreement with previous study reports (Lemeniha and Itanna 2004; Vagen et al. 2005).

Figure 3 indicates the trends of SOC stocks in cultivated lands and fallow lands along Didessa toposequence. The stocks of SOC in cultivated and fallow lands increased with topographic elevation. The increasing trends of SOC stocks with increasing topographic elevation presumably related to low mineralization and higher stabilization of SOC due to relatively lower temperature in the higher topographic elevation. A similar trend of SOC stocks in the same toposequence was also reported earlier by Abdenna et al. (2018). In the study 
Table 2 Some chemical properties of soils and durations of land use catena in the transect

\begin{tabular}{|c|c|c|c|c|c|c|}
\hline Districts & Sites & Land uses & Duration (year) & $C(\%)$ & $\rho b, \mathrm{~g} \mathrm{~cm}^{-3}$ & $\begin{array}{l}\text { C stocks, } \\
\mathrm{Mg} \mathrm{Cha}^{-1}\end{array}$ \\
\hline \multirow[t]{9}{*}{ Guto Gidda } & Fayinera & Coffee agroforestry & 50 & 7.31 & 0.83 & 12.18 \\
\hline & & Eucalyptus agroforestry & 10 & 6.41 & 1.12 & 14.29 \\
\hline & & Cultivated land & 40 & 4.75 & 1.08 & 10.27 \\
\hline & & Short fallow & 3 & 5.20 & 1.07 & 11.13 \\
\hline & Dune Kane & Coffee agroforestry & 22 & 6.33 & 0.87 & 11.01 \\
\hline & & Protected forest & 22 & 5.92 & 1.02 & 12.07 \\
\hline & & Eucalyptus agroforestry & 15 & 5.67 & 1.12 & 12.71 \\
\hline & & Cultivated land & & 4.39 & 1.08 & 9.49 \\
\hline & & Short fallow land & 3 & 4.52 & 1.09 & 9.83 \\
\hline \multirow[t]{4}{*}{ Diga } & Jirata & Eucalyptus agroforestry & 15 & 4.85 & 1.12 & 10.81 \\
\hline & & Cultivated land & 2 & 4.58 & 1.12 & 10.29 \\
\hline & & Short fallow & 3 & 4.71 & 1.08 & 10.19 \\
\hline & & Coffee agroforestry & 15 & 5.14 & 0.88 & 9.00 \\
\hline \multirow[t]{6}{*}{ Leka Dulacha } & Near catholic & Cultivated land & & 4.03 & 1.26 & 10.14 \\
\hline & & Eucalyptus agroforestry & 15 & 4.24 & 0.99 & 8.42 \\
\hline & & Short fallow & 3 & 4.61 & 1.19 & 10.94 \\
\hline & Balho & Grazing land & 8 & 6.16 & 1.24 & 15.21 \\
\hline & & Forest land & 12 & 8.44 & 0.74 & 12.43 \\
\hline & & Cultivated land & 40 & 5.69 & 1.13 & 12.88 \\
\hline \multirow[t]{3}{*}{ Bedele } & Sugarcane & Sugar plantation at harvest & 3 & 4.46 & 1.49 & 13.31 \\
\hline & & Grassland & & 3.39 & 1.32 & 8.93 \\
\hline & & Sugarcane plantation & 3 & 3.49 & 1.29 & 9.04 \\
\hline \multirow[t]{3}{*}{ Jimma Arjo } & Sugarcane & Grassland & & 4.17 & 1.15 & 9.60 \\
\hline & & Sugar plantation at harvest & 3 & 4.18 & 1.44 & 12.03 \\
\hline & & Sugar plantation & 3 & 2.75 & 1.25 & 7.41 \\
\hline
\end{tabular}

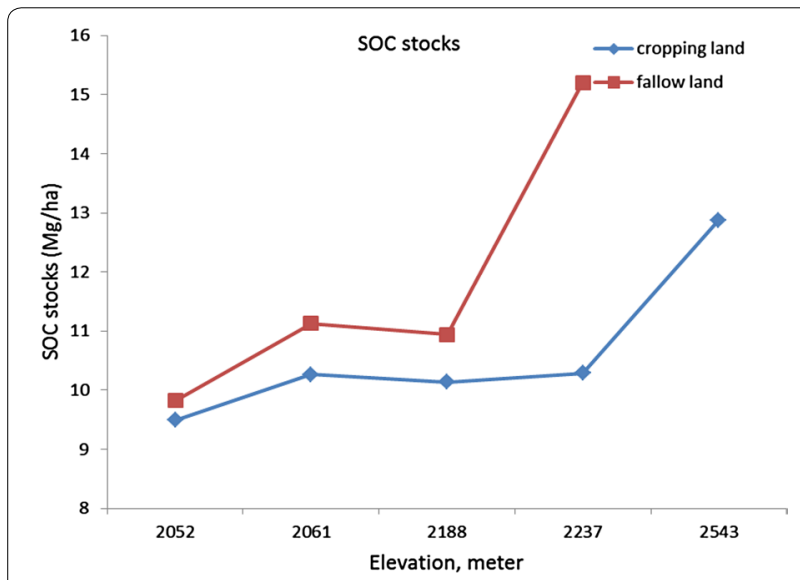

Fig. 3 Soil organic carbon stocks in cultivated and fallow lands along Didessa toposequence

toposequence, farmers fallow their land for three to four years to restore soil fertility. This practice of short fallowing consistently increased the SOC stocks compared with continuous cultivation. The increased SOC stocks under fallow system in this study are in agreement with many research reports from tropical Africa and Latin America (Vagen et al. 2005; Styger and Fernandes 2006).

Soil organic carbon stocks in irrigated sugarcane plantation in lower topographic position in Didessa toposequence ranged from 7.41 to $13.31 \mathrm{Mg} \mathrm{C} \mathrm{kg}^{-1}$ (Table 2). Higher SOC stocks were sequestered during harvesting of sugarcanes as compared to just before harvest of the sugarcanes. The higher SOC stocks during harvesting of sugarcanes were due to incorporation of leafy biomass of the sugarcanes to the soil system during harvesting. The higher the stocks of SOC in mechanized irrigated sugarcane plantation were also in agreement with several study reports from Brazilian sugarcane production systems (Junior et al. 2012; Aline et al. 2013; Ensinas et al. 2015). They reported that cultivation of sugarcane plantations increased the stocks of SOC. Similar ranges of stocks of SOC in sugarcane plantations were also reported by Junior et al. (2012). As compared to our study results, higher stocks of SOC in smallholder irrigation based fruit production system in Northern Ethiopia were reported (Aweke et al. 2014). They reported $17.47 \mathrm{Mg} \mathrm{C} \mathrm{ha}^{-1}$ in 
irrigated fruit production system and $9.8 \mathrm{Mg} \mathrm{C}^{-1}$ in rain fed annual arable cropping system in the upper $0-20 \mathrm{~cm}$ soil surface. The reasons for the lower SOC stocks in irrigated sugarcane plantations could be due to the humid regional climate which facilitated mineralization of soil organic matter, and the low inherent $\mathrm{C}$ storage capacity of Alfisols and Ultisols of the humid tropical region (Lal 2004a). According to Aweke et al. (2014) the climate in North Western Ethiopia was semiarid with mean annual precipitation of $558 \mathrm{~mm}$ with Arenosols and Cambisols developed on alluvial deposits and Adigrat sandstone parent materials. Moreover, the lower stocks of SOC in our study thus could be due to high mineralization as favored by longer period of wet season and the residue quality returned to the soil system.

The stocks of SOC in eucalyptus agroforestry ranged from 8.42 to $14.29 \mathrm{Mg} \mathrm{C} \mathrm{kg}^{-1}$ (Table 2). The mean stocks of SOC in eucalyptus agroforestry system were higher than the mean stocks of SOC in annual arable cropping system in the highland. The stocks of SOC in eucalyptus agroforestry system were consistently higher than the stocks of SOC in arable cropping. The stocks of SOC along toposequence didn't show consistent trend due to many uncontrolled factors such as level of soil erosion, slope variation and slight variation in duration of eucalyptus agroforestry. The higher the stocks of SOC under eucalyptus agroforestry could be explained by higher biomass productions, higher C:N ratios, higher soil bulk density, and production and release of allelochemicals. Eucalyptus species produce and release allele-chemicals into rhizosphere, which inhibit the growth, development and functioning of microbes. Eucalyptus species also produce large quantities of litter materials with high C:N ratios, high lignin and phenolic content (Snowdon et al. 2005; Silva 2012). Mulugeta et al. (2004) also reported higher C:N ratios of surface soils under eucalyptus species as compared to natural forests in Southern Ethiopia. Poultouchidou (2012) also reported increased stocks of SOC in soils from eucalyptus species and Silva (2012) also reported increased soil compaction, bulk density, and stocks of SOC as the result of conversion of pasture land into eucalyptus agroforestry in Brazil which are in agreement with our finding.

The stocks of SOC from coffee agroforestry system ranged from 9.0 to $12.18 \mathrm{Mg} \mathrm{C} \mathrm{kg}^{-1}$ and the stocks of SOC were higher compared with the nearby stocks of SOC from annual arable cropping system (Table 2). The variations in stocks of SOC were due to variation chronology (ages) of the coffee agroforestry (Fig. 4). The stocks increased with duration (ages) of coffee agroforestry stands. The stocks of SOC in the coffee agroforestry system from our study were lower than the stocks of SOC of $21 \mathrm{Mg} \mathrm{C} \mathrm{ha}{ }^{-1}$ from 32 years old coffee agroforestry

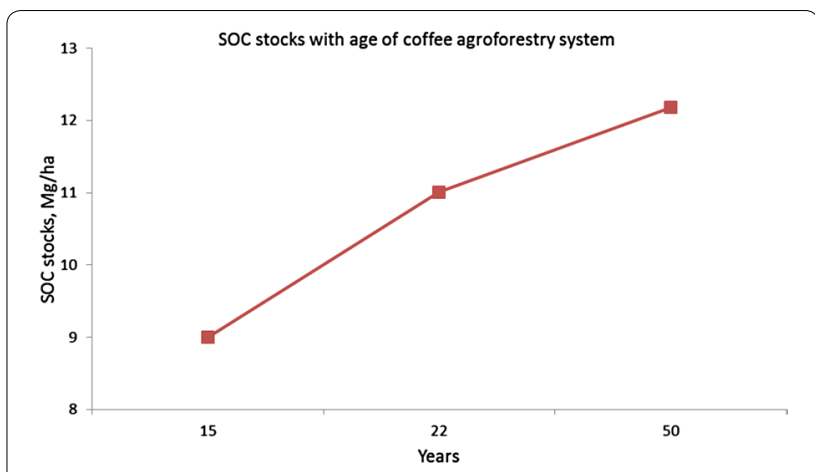

Fig. 4 Soil organic carbon stocks with age of coffee agroforestry system

established on Andosols of Central Rift Valley of Ethiopia (Girma and Wolde-Meskel 2012). The low stocks of SOC stocks in coffee agroforestry in Didessa toposequence compared with the Central Rift Valley of Ethiopia could be due to difference in the soil types (Luvisols and Alisols) which inherently have lower sequestration capacity of stocks of SOC, and the favorable humid tropical climate of Western Ethiopia for higher mineralization, hence low stocks. The Andosols from Central Rift valley of Ethiopia favor stocks of SOC through decreasing mineralization due to moisture deficiency. Moreover, Lal (2004a) also reported that Andosols sequester more SOC than Luvisols and Alisols. Xavier and Mendo (2011) also reported higher stocks of SOC that ranged from 28.5 to 31.4 Mg C ha ${ }^{-1}$ in 0-10 cm from Brazilian coffee agroforestry system compared with stocks of SOC from coffee agroforestry system in our report. The stocks of SOC in the $0-20 \mathrm{~cm}$ depth in this Brazilian coffee agroforestry system could be even much higher than the SOC stocks in the current study coffee agroforestry system. The higher the value of SOC stocks (32.24 $\left.\mathrm{Mg} \mathrm{C} \mathrm{ha}^{-1}\right)$ in small holder coffee agroforestry system in Western highlands of Gautama was also reported by Schmitt-Harsh et al. (2012).

The stocks of SOC in grazing land in Didessa toposequence ranged from 8.91 to $15.21 \mathrm{Mg} \mathrm{C} \mathrm{kg}^{-1}$ (Table 2). The mean stocks of SOC from grazing land use systems were higher compared with the stocks of SOC from arable cropping system (reference land use). Rimhanen et al. (2016) also reported comparable stocks of SOC in restrained grazing from Kobo district of Northern Ethiopia. They also reported higher stocks of SOC from grazing land use from Sire district of Central Rift Valley of Ethiopia with stocks of SOC ranging from 18 to $59 \mathrm{Mg} \mathrm{Cha}^{-1}$ in the upper $30 \mathrm{~cm}$ surface soil layer. These corresponded to stocks of SOC of 12 to $39 \mathrm{Mg} \mathrm{ha}^{-1}$ that were compareable to our finding from graizing lands. The 
Table 3 Soil carbon stocks along a transect toposequence in Didessa watershed

\begin{tabular}{lll}
\hline Sites & \multicolumn{2}{l}{ SOC Stocks, $\mathbf{M g ~ h a}^{\mathbf{1}}$} \\
\cline { 2 - 3 } & Mean* & Std. Error \\
\hline Balho & $14.045 \mathrm{~b}$ & 1.188 \\
Catholic & $10.540 \mathrm{a}$ & 1.188 \\
Dune Kane & $10.760 \mathrm{ab}$ & 0.84 \\
Fayinera & $11.968 \mathrm{ab}$ & 0.84 \\
sugar plantation & $10.967 \mathrm{ab}$ & 0.84 \\
\hline
\end{tabular}

* Means in a column followed by the same small letter are not statistically significant at $\mathrm{P}<0.05$ using Tukey test

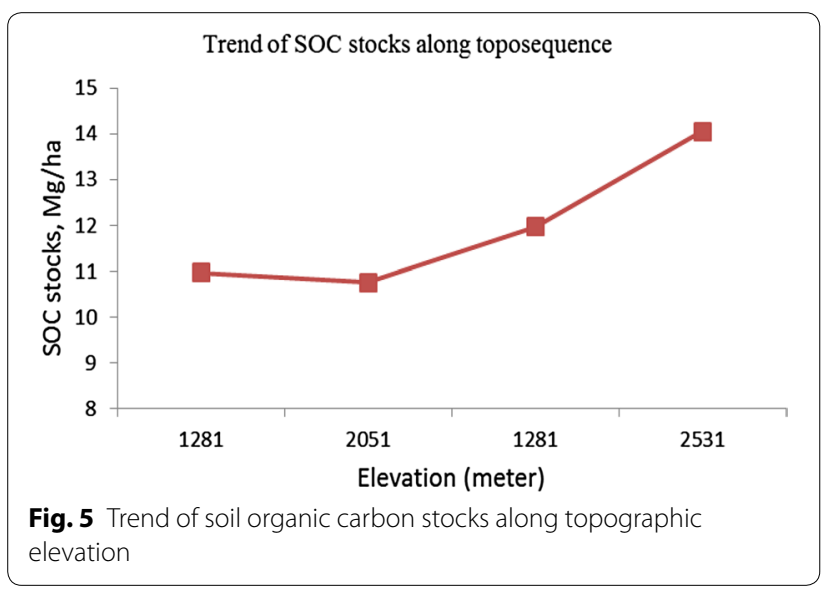

stocks of SOC from grazing land use system of our study results were lower than the stocks of SOC from Kobo district of North Eastern Ethiopia. The stocks of SOC in our results were in the lower margin of SOC stocks reported from Sire district of Central Rift Valley of Ethiopia (Rimhanen et al. 2016). The difference in precipitation, temperature and soil types could be attributed to the difference in stocks of SOC in both locations. As compared to our result, higher stocks of SOC of magnitude of $39.31 \mathrm{Mg} \mathrm{C}^{-1}$ from open grazing land use from the upper $0-20 \mathrm{~cm}$ in a semi-arid in Tigray in the Northern Ethiopia was also reported by Aweke et al. (2014).

\section{Soil organic carbon stocks along toposequence}

Table 3 indicates the mean stocks of SOC in the upper $0-20 \mathrm{~cm}$ soil surface layers from different locations along toposequence in the mixed farming systems along Didessa toposequence. The stocks of SOC ranged from $10.54 \mathrm{Mg} \mathrm{C} \mathrm{ha}{ }^{-1}$ at mechanized irrigated sugarcane production system to $14.045 \mathrm{Mg} \mathrm{C} \mathrm{ha}^{-1}$ at Balho site. The higher the stock of SOC at Balho site was significantly $(\mathrm{P}<0.05)$ higher compared with other sites along Didessa toposequence. The trend of stcoks of SOC increased with increased topographic elevation (Fig. 5) along the increasing precipitation and decreasing temperature paterns. The higher SOC stock at Balho was due to cooler weather and longer growth periods (Abdenna et al. 2018). The observed pattern was due to the effect of precipitation and temperature. Similar observed pattern of increasing SOC stocks with increasing topographic elevation was also reported ealier in Southern Ethiopia (Lemeniha and Itanna 2004) and in South Eastern Ethiopia (Yimer et al. 2006).

\section{Soil organic carbon retention among land uses}

Table 4 indicates the mean annual SOC retention rates in different land uses of mixed farming systems along Didessa toposequence. In reference to annual arable cropping system for midland and highland, and grassland for lowland systems, the annual retention rates ranged from 0.114 to $1.14 \mathrm{Mg} \mathrm{C} \mathrm{ha}^{-1}$ year $^{-1}$ that there were statistically significantly $(\mathrm{P}<0.05)$ different among SOC retention rates. These results were in the range of SOC retention rates ( -0.98 to $1.91 \mathrm{Mg} \mathrm{C}^{-1}$ year $^{-1}$ ) reported in major agroforestry systems in tropical Africa (Feliciano et al. 2018). The magnitudes of SOC retention rates revealed that retention rate in irrigated

Table 4 Soil carbon stocks and retentions in a transect along a toposequence in Didessa watershed

\begin{tabular}{|c|c|c|c|c|}
\hline \multirow[t]{2}{*}{ Land uses } & \multicolumn{2}{|c|}{ SOC Stocks, $\mathrm{Mg} \mathrm{ha}^{-1}$} & \multicolumn{2}{|c|}{ SOC retentions, $\mathrm{Mg} \mathrm{ha}^{-1}$ year $^{-1}$} \\
\hline & Mean* & Std. Error & Mean $^{* *}$ & Std. Error \\
\hline Cropping land (reference-highland) & $10.695 a b$ & 0.739 & - & - \\
\hline Grass land (reference-lowland) & $9.265 b$ & 1.045 & - & - \\
\hline Coffee agroforestry & $11.595 \mathrm{ab}$ & 1.045 & $0.114 b$ & 0.073 \\
\hline Fallow land & $10.48 a b$ & 1.045 & $0.200 b$ & 0.073 \\
\hline Grazing land & $13.075 a$ & 1.045 & $0.279 b$ & 0.073 \\
\hline Eucalyptus agroforestry & $13.5 \mathrm{a}$ & 1.045 & $0.308 b$ & 0.073 \\
\hline Sugar plantation & $12.67 \mathrm{ab}$ & 1.045 & $1.135 a$ & 0.073 \\
\hline
\end{tabular}

Means under the column * followed by the different small letter are statistically significant at $P \leq 0.05$ but not at $P \leq 0.01$ using Dunken multiple range test, while Means under column ** followed by the different small letter are statistically significant at $P \leq=0.05$ using Tukey test 
sugarcane plantation system > eucalyptus agroforestry system $>$ grazing land use system $>$ fallow land use system. The mechanized irrigated sugarcane production located at the lowland topographic position resulted in more retention of SOC compared with the nearby reference pristine grassland system. The positive SOC retention rate in sugarcane production system was due higher sugarcane biomass production. The higher biomass production was due to fertilization of sugarcane plantation with supplemental irrigation water during dry season, and incorporation of sugarcane residues into the soil system at the time of harvesting of sugarcanes. Our results are comparable with SOC retention rates in conventional tillage $\left(0.67 \mathrm{Mg} \mathrm{C} \mathrm{ha}^{-1}\right.$ year $\left.^{-1}\right)$, and zero tillage (1.63 $\mathrm{Mg} \mathrm{C} \mathrm{ha}^{-1}$ year $^{-1}$ ) from Brazilian sugarcane production system as reported by Aline et al. (2013). They attributed the positive retention rates of SOC to the maintenance of sugarcane straws and incorporation to soils at the time of harvesting of the sugarcanes. The annual retention rate of SOC in sugarcane plantation in our study was higher than the SOC retention rate of $0.56 \mathrm{MgC} \mathrm{ha}^{-1}$ year $^{-1}$ in smallholder irrigation fruit production system in semiarid Northern Ethiopia (Aweke et al. 2014).

The mean magnitude of SOC retention rate in eucalyptus agroforestry system along Didessa toposequence was $0.308 \mathrm{Mg} \mathrm{C} \mathrm{ha}^{-1}$ year $^{-1}$. It is comparable with the SOC retention rates reported earlier by Aweke et al. (2014) in Faidherbia albida silvopasture $\left(0.46 \mathrm{Mg} \mathrm{C} \mathrm{ha}^{-1} \mathrm{year}^{-1}\right)$, and Faidherbia albida agroforestry system (0.19 Mg C ha ${ }^{-1}$ year $\left.^{-1}\right)$ from semiarid Northern Ethiopia. The retention rate of SOC in eucalyptus agroforestry system was higher than the SOC retention rates of agroforestry system $\left(1.2 \mathrm{Mg} \mathrm{C}^{-1} \mathrm{year}^{-1}\right)$, and restrained grazing $\left(0.7 \mathrm{Mg} \mathrm{ha}^{-1}\right.$ year $\left.^{-1}\right)$ in Kobo district of Northern Ethiopia and Sire district of Rift valley of Ethiopia (Rimhanen et al. 2016).

The SOC retention rate in grazing land use system was $0.279 \mathrm{Mg} \mathrm{C} \mathrm{ha}^{-1} \mathrm{year}^{-1}$. The magnitude of the SOC retention in the grazing land in our result was lower than the SOC retention in open pasture $\left(0.73 \mathrm{Mg} \mathrm{C} \mathrm{ha}^{-1}\right.$ year $\left.^{-1}\right)$, and silvo-pasture $\left(0.46 \mathrm{Mg} \mathrm{C}^{-1}\right.$ year $\left.^{-1}\right)$ in semiarid Northern Ethiopia (Aweke et al. 2014). Moreover, the SOC retention rate in grazing land in our finding was lower than SOC retention of restrained grazing $(0.7 \mathrm{Mg}$ $\mathrm{C} \mathrm{ha}{ }^{-1}$ year $^{-1}$ ) in Kobo district of Northern Ethiopia and Sire district of Rift valley of Ethiopia (Rimhanen et al. 2016). The lowest SOC retention rate in our finding was obtained from fallow land use system. The relatively small SOC retention rate in fallow land use system was due to short fallow duration $(<2$ years) from which the land could not get enough time for vegetation restoration that produces biomass the returns vegetal materials to the soil system.

\section{Soil organic carbon retention rates along toposequence} Figure 6 indicates trends of SOC retention rates among three land uses along toposequence of Didessa watershed. The trends indicated decreasing retention rates of SOC with increasing topographic elevation. Eucalyptus agroforestry and fallow land use systems were more efficient in retention rates of SOC compared with coffee agroforestry system. The lower retention rates with increasing topographic elevation could be due to higher precipitation and moisture over longer growing period that led to more mineralization of SOC, and the vice versa. Moreover, with increasing topographic position, the landscape gets steeper and soil erosion becomes severe leading to removal of organic materials that could ultimately decrease the rate of SOC retention. Bajigo et al. (2015) also reported higher SOC retention rates in lower topographic elevation in agroforestry practices in Gununo watershed in Southern Ethiopia. They attributed to higher retention rates in lower topographic position due to dense vegetation. Feliciano et al. (2018) also reported the order of retention rates of SOC in the order of tropical $>$ semiarid $>$ temperate climate indicating the importance of climate on SOC retention rates.

\section{Conclusion and recommendation}

Traditional coffee agroforestry, eucalyptus agroforestry, grazing land and irrigated sugarcane production system practiced in Western Ethiopia sequester SOC and moderate the loss of SOC stocks in the form of $\mathrm{CO}_{2}$ into the atmosphere. Traditional coffee agroforestry, eucalyptus agroforestry, and traditional grazing systems practiced by local communities and the recent introduction of mechanized irrigated sugarcane system into pristine grassland sequester and restore considerable amount of SOC stocks in the upper soil layers. The

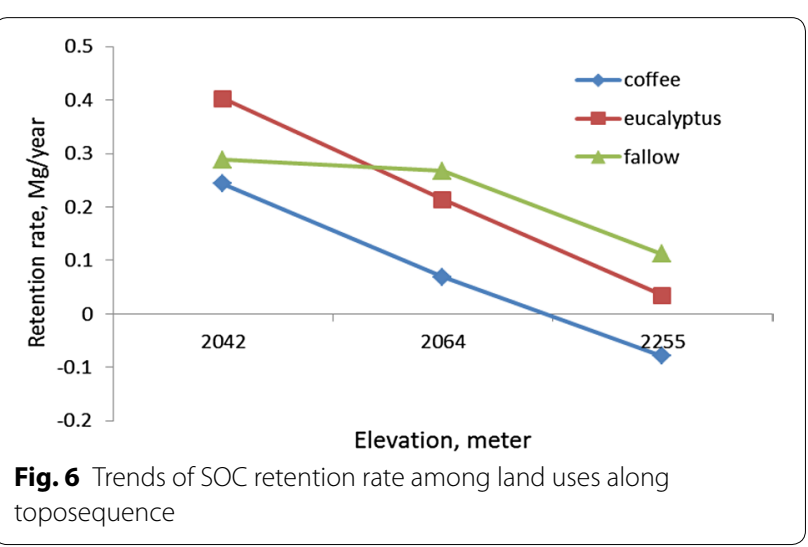


annual efficiency of SOC stocks sequestration potential followed the order of sugarcane plantation $>$ eucalyptus agroforestry $>$ grazing land $>$ short fallow land $>$ coffee agroforestry systems. The annual SOC retention rates of these indigenous land use systems practiced along the toposequence and the recent introduced mechanized irrigated sugarcane plantation revealed that the systems are efficient in sequestering $\mathrm{C}$ and could be considered as SOC stock restorative land use systems. Thus, mixed land use systems restore SOC, besides sustainably provision of goods and services that have both economic and ecological significances. Adoption of these restorative land use systems could provide economic and social values, sequester SOC stocks, and restore degraded lands in humid tropical Western Ethiopia.

\section{Abbreviations}

ACZ: Agro-climatic zone; C: Carbon; $\mathrm{CO}_{2}$ : Carbon dioxide; Gt: Gigatone; LGP: Length of growing period; SOC: Soil organic carbon; SOM: Soil organic matter.

\begin{abstract}
Acknowledgements
The authors would like to thank the Ministry of Education and Wollega University of the Federal Democratic Republic of Ethiopia for funding the research project. Wollega University was also acknowledged for provision of logistics and support during field works. Moreover, we extend our gratitude to ArjoDidessa Sugar Development Enterprise for allowing us to collect soil samples and provision of vehicle and field guidance during field work, and Nekemte Soil Research Center for provision of support during soil laboratory analysis.
\end{abstract}

\section{Authors' contributions \\ The research work was conducting to aid the interpretation of Ph.D. dis- sertation of AD author at Haramaya University. AD who is the first author developed the concept note, conducted the research work and prepared the research manuscript for publication, while the co-authors (MY and MM) sup- ported the write up and interpretation of the results. The coauthors reviewed, commented and endorsed the manuscript for publication. All authors read and approved the final manuscript.}

\section{Funding}

Wollega University (Grant No. 016/06) and Ministry of Education of FDR Ethiopia funded the study.

\section{Availability of data and materials} Not applicable.

\section{Ethics approval and consent to participate}

The manuscript does not contain data or information from any person or individual apart from field and laboratory investigation. All data and information are generated and synthesized by first author and approved by the co-authors.

\section{Consent for publication}

Not applicable.

\section{Competing interests}

The authors declare that they have no competing interests.

\section{Author details}

${ }^{1}$ College of Agriculture and Natural Resources Management, Wollega University, Nekemte, Ethiopia. ${ }^{2}$ Faculty of Agriculture and Forestry, Agricultural Sciences, University of Helsinki, Helsinki, Finland. ${ }^{3}$ West Hararghe Zone of Oromia Region, Oda Bultum University, Chiro, Ethiopia.
Received: 10 September 2020 Accepted: 13 November 2020

Published online: 24 November 2020

\section{References}

Abdenna D, Yli-Halla M, Muktar M, Lemma W (2018) Soil classification of humid Western Ethiopia: a transect study along a toposequence in Didessa watershed. CATENA 163:184-195

Abraha K, Heluf G, Tekalign M, Kibebew K (2012) Impact of altitude and land use type on some physical and chemical properties of acidic soils in Tsegede highlands, Northern Ethiopia. Open J Soil Sci 2:223-233

Achalu C, Heluf G, Abi T, Kibebew K (2013) Phosphorus sorption patterns of soils from different land use systems of East Wollega, Ethiopia. AmEurasian J Sci Res 8(3):109-116

Aline SJ, Luis NC, Denizart B, Débora BPM, Wilson TLS, Marcelo LS, Heitor C, Isabella M, Ladislau M (2013) Carbon stock and humification index of organic matter affected by sugarcane straw and soil management. Scientia Agricola 70(5):321-326

Aweke MG, Singha BP, Lal R (2014) Soil organic carbon and total nitrogen stocks under different land uses in a semi-arid watershed in Tigray, Northern Ethiopia. Agr Ecosyst Environ 188:256-263

Bajigo A, Tadesse M, Moges Y, Anjulo A (2015) Estimation of carbon stored in agroforestry practices in Gununo Watershed, Wolayitta Zone, Ethiopia. J Ecosys Ecograph 5(1):1-5. https://doi.org/10.4172/2157-625.1000157

Bishaw B, Henry N, Jeremias M, Abdu A, Jonathan M, Gemedo D, Tewodros A, Kathleen G, Habtemariam K, lan KD, Eike L, Cheikh M (2013) Farmers' strategies for adapting to and mitigating climate variability and change through agroforestry in Ethiopia and Kenya. Forestry Communications Group. p. 96

Conway D (2000) The climate and hydrology of the upper blue Nile river. Geogr J 166:49-62

Dawit S, Lehmann J, Fritzsche F, Zech W (2002) Phosphorus forms and dynamics as influenced by land use changes in the sub-humid Ethiopian highlands. Geoderma 105:21-48

Ensinas SC, Serra AP, Marchetti MS, Silva EF, Prado FE, Lourente ERP, Conrad VA, Altomar PH, Potrich DC, Chaim CB, Rosa J, Martinez MA, Silva M, Renata A (2015) Effects of sugarcane cropping on organic carbon properties of the soils. Aust J Crop Sci 9(11):1042-1048

ESA (2000) Carbon sequestration in soils. Ecological society of America. Washington D.C., http://www.esa.org.esahq@esa.org

FAO (2006) Guidelines for soil description, 4th edn. Food and Agricultural Organization of the United Nations, Rome

FAO (2010) Global forest resource assessment: Country report-Ethiopia. Food and Agricultural Organization of the United Nations, Rome

Feliciano D, Ledo A, Hillier J, Nayaka DR (2018) Which agroforestry options give the greatest soil and above ground carbon benefits in different world regions? Agr Ecosyst Environ 254:117-129

Getahun B, Bobe B (2015) Impact of land use types on selected physicochemical properties of Loma Woreda, Dawuro Zone, Southern Ethiopia. STAR J Wollega Univ 4(4):40-48

Girma A, Wolde-Meskel E (2012) Soil properties and soil organic carbon stocks of tropical Andosol under different land uses. Open J Soil Sci 3(3):153162. https://doi.org/10.4236/ojss.2013.33018

Henry M, Valentini R, Bernoux M (2009) Soil carbon stocks in eco-regions of Africa. J Biogeosci Discuss 6:797-823

Hombegowda HC, Straaten OV, Kohler M, Holscher D (2015) On the rebound: soil organic carbon stocks can bounce back to near forest levels when agroforests replace agriculture in southern India. J Soil Discuss 2:871-902

Hurni H (1998) Research report on agro-ecological belts of Ethiopia. Soil conservation research program and center for development and environment, University of Bern, Switzerland in association with the ministry of agriculture, Addis Ababa, Ethiopia

Junior L, Figueiredo D, Panosso AR (2012) A review on soil carbon accumulation due to the management change of major Brazilian agricultural activities. Braz J Biol 72(3):775-785

Kilic K, Kilic S, Kocyigit R (2012) Assessment of spatial variability of soil properties in areas under different land use. Bulgar Jo Agric Sci 18(5):722-732

Kroetsch D, Wang C (2006) Particle size distribution. In: Carter MR, Gregorich EG (Eds) Soil sampling and methods of analysis. Second edition. Taylor and Francis Group 
Lal R (2004a) Soil carbon sequestration to mitigate climate change. Geoderma 123:1-22

Lal R (2004b) Soil carbon sequestration impacts on global climate change and food security. Science 304:623-627

Lal R (2005) Forest soils and carbon sequestration. For Ecol Manage 220:242-258

Lal R (2006) Impacts of climate on soil systems and of soil systems on climate. In: Norman U, Andrew SB, Erick F, Hans H, Olivier H, Mark L, Cheryl P, Jules P, Sanchez P, Nteranya S, Janice T (Eds), Biological approaches to sustainable soil systems CRC Press Taylor \& Francis Group

Lemeniha M, Itanna F (2004) Soil carbon stocks and turnovers in various vegetation types and arable lands along an elevation gradients in Southern Ethiopia. Geoderma 123:177-188

Mulugeta L, Olsson M, Karltun E (2004) Comparison of soil attributes under Cupressus lusitanica and eucalyptus saligna established on abandoned farmlands with continuously cropped farmlands and natural forest in Ethiopia. For Ecol Manage 196:57-67

Murthy IK, Gupta M, Tomar S, Munsi M, Tiwari R (2013) Carbon sequestration potential of agroforestry systems in India. J Earth Sci Clim Change 4(1):1-7. https://doi.org/10.4172/2157-7617.1000131

Nega E, Heluf G (2013) Effect of land use changes and soil depth on soil organic matter, total nitrogen, and available phosphorus contents of soils of Senbet watershed, Western Ethiopia. ARPN J Agric Biol Sci 8(3):1-7

Oelbermann M, Voroney RP, Gordon AM (2007) Carbon sequestration in tropical and temperate agroforestry systems: a review with examples from Costa Rica and Southern Canada. Agr Ecosyst Environ 104:359-377

Poultouchidou A (2012) Effects of forest plantations on soil carbon sequestration and farmers' livelihoods: A case study in Ethiopia. Master thesis in biology, forest as natural resources-master's program, department of soil and environment, Swedish University of Agricultural Sciences, Uppsala. p. 73

Prasad JVN, Srinivas K, Srinivasa CR, Ramesh C, Venkatravamma K, Venkateswarlu B (2012) Biomass productivity and carbon stocks of farm forestry and agroforestry systems of leucaena and eucalyptus in Andhra Pradesh, India. J Curr Sci 103(5):536-540

Reeuwijk VJL (1992) Procedure for soil analysis. International soil reference information center, Wageningen (ISRIC), 6700 AJ Wageningen
Rimhanen K, Ketoja E, Yli-Halla M, Kahiluoto H (2016) Ethiopian agriculture has greater potential for carbon sequestration than previously estimated. Glob Change Biol 22:3739-3749. https://doi.org/10.1111/gcb.13288

Schmitt-Harsh M, Evans TP, Castellanos E, Randolph JC (2012) Carbon stocks in coffee agroforests and mixed dry tropical forests in the western highlands of Guatemala. Agroforestry Systems 86 (2):141-157

Silva MR (2012) Impact of eucalyptus plantations on pasture land on soil properties and carbon sequestration in Brazil. Master thesis, Swedish University of agricultural science program, p 59

Sima BA, Kevin B, Solomon G (2011) Flow regime and land cover changes in the Didessa sub basin of the Blue Nile River, South-Western Ethiopia: combining empirical analysis and community perception, Master thesis, Uppsala, Swedish University of agricultural sciences (SLU)

Snowdon P, Ryan P, Raison J (2005) Review of C:N ratios in vegetation, litter and soil under Australian native forests and plantations, National carbon accounting system technical Report No. 45, CSIRO forestry and forest products

Styger E, Fernandes ECM (2006) Contributions of managed fallows to soil fertility recovery. In: Norman Uphoff (ed.), Biological approaches for sustainable soil systems. pp 425-438. Taylor \& Francis Group

Vagen TG, Lal R, Singh BR (2005) Soil carbon sequestration in sub-Saharan Africa: a review. Land Degrad Dev 16:53-71. https://doi.org/10.1002/ Idr.644

Wakene NC (2001), Assessment of important physicochemical properties of dystric Udalf (dystric Nitosols) under different management systems in Bako area, Western Ethiopia, Master thesis, Alemaya University, Ethiopia

Xavier FAS, Mendo E (2011) Agroforestry for recovering soil organic matter: a Brazilian perspective. J Dyn Soil Dyn Plant Glob Sci Books 5(1):45-52

Yimer F, Ledin S, Abdelkadir A (2006) Soil organic carbon and total nitrogen stocks as affected by topographic aspect and vegetation in the Bale Mountains, Ethiopia. Geoderma 135:335-344

\section{Publisher's Note}

Springer Nature remains neutral with regard to jurisdictional claims in published maps and institutional affiliations.

\section{Submit your manuscript to a SpringerOpen ${ }^{\odot}$ journal and benefit from:}

- Convenient online submission

- Rigorous peer review

- Open access: articles freely available online

- High visibility within the field

- Retaining the copyright to your article

Submit your next manuscript at $\boldsymbol{\nabla}$ springeropen.com 